\title{
Ribonuclease P Protein Subunit p40
}

National Cancer Institute

\section{Source}

National Cancer Institute. Ribonuclease P Protein Subunit p40. NCI Thesaurus. Code C104725.

Ribonuclease P protein subunit p40 (363 aa, $\sim 42 \mathrm{kDa}$ ) is encoded by the human RPP40 gene. This protein is involved in cleavage of tRNA molecules. 